\title{
How to publish biomedical research in "non-predatory" journals: a discussion and notes from experts
}

\author{
Askhat Myngbay, ${ }^{1}$ Zulfiya Orynbayeva, ${ }^{2}$ Kuat Oshakbayev, ${ }^{3}$ Abduzhappar Gaipov ${ }^{4}$
}

\begin{abstract}
"Private Institution "National Laboratory Astana", Nazarbayev University, Astana, Kazakhstan; ${ }^{2}$ Department of Surgery, Drexel University College of Medicine, Philadelphia, PA, USA;

${ }^{3}$ Metabolic Syndrome Department, Nazarbayev University Medical Center, Astana, Kazakhstan;

${ }^{4}$ Department of Extracorporeal Hemocorrection,
\end{abstract}

National Scientific Medical Center, Astana, Kazakhstan. On behalf of Editorial and Advisory Board of Journal of Clinical Medicine of Kazakhstan.

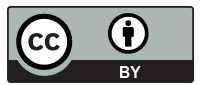

This work is licensed under a Creative Commons Attribution 4.0

Received: 2018-03-15

Accepted: 2018-04-18

UDC: $616.12-008.313 .2-07$

J Clin Med Kaz 2018;2(48):6-8

\author{
БИОМЕДИЦИНАЛЫҚ ЗЕРТТЕУЛЕРДІ «ЖЫРТҚЫШ \\ ЕМЕС» ЖУРНАЛДАРДА ҚАЛАЙ ЖАРИЯЛАУҒА БОЛАДЫ: \\ САРАПШЫЛАРДАН ТАЛҚЫЛАУ ЖӘНЕ ЕСКЕРТУЛЕР \\ Асхат Мыңбай, Зүлфия Орынбаева, Қуат Ошақбаев, Абдужаппар Гаипов
}

КАК ПУБЛИКОВАТЬ БИОМЕДИЦИНСКИЕ ИССЛЕДОВАНИЯ В «НЕ ХИЩНИЧЕСКИХ» ЖУРНАЛАХ: ОБСУЖДЕНИЕ И ЗАМЕТКИ ЭКСПЕРТОВ

Асхат Мынбай, Зульфия Орынбаева, Куат Ошакбаев, Абдужаппар Гайпов
It has become a trend among Kazakhstani researches to publish in "Predatory" journals, which are, while initially indexed, then retracted from the peer-reviewed literature databases. The featured Beall's list of Predatory Publishers established by Jeffrey Beall from the University of Colorado in Denver, USA since 2008 annually analyzed and revealed potential predatory journals from various publishers based on 48 criteria [1]. By the end of 2016, the list included around 1,000 publishers and journals. While the list was considered controversial and was variously accepted by scientists and libraries, it raised an important problem of growing number of "Fake Journals" which do not practice the robust, yet "painful" review process but aim to receive easy money via publishing of low-quality scientific works. Thus in 2017 after a thorough investigation, 299 journals were withdrawn from Scopus. The analysis shows that one third of Kazakhstani researchers working in the field of biomedicine became victims of such journals [2]. Examples of fake journals popular among Kazakhstani scientists are the
"Journal of Environmental and Science Education" and "Man in India". About 200 and 100 articles were published in these journals in 2016 correspondingly [3]. These numbers are large enough to alarm researchers on the overall misunderstanding of the publishing practice. The objective of this letter is to help researchers understand the concept of scholarly publishing and navigate them through choosing the right journals for submitting their manuscripts.

First, the question begins with the quality of the study itself. If the experimentation was thoroughly planned out through every detail, repeated many times using different methods, and the accuracy of the hypothesis was confirmed, then it is most likely that the authors will pursue high impact journals, regardless of the difficulty of the revision process by addressing multiple concerns, and the time spent on performing additional experiments per reviewers request, which significantly lengthens the process of publication. If this is not the case, then the low impact or perpetuate journals are targeted to get a 
publication record, rather than to share important findings with the international scientific community. Often, authors do not choose "predatory" journals intentionally, and are attracted by the publishers' deceptive advertising $[4,5]$. The consequences may be very serious, even possibly leading universities to either dismiss such manuscripts or ask for the refunding of supported research grants. In the end, this misbehavior affects researchers' reputation. Unfortunately, the fraud journals industry is becoming a business and knowing the publication process established by reputational journals would be of great help for both established and young researchers.

\section{How to discern the fake journals and avoid getting on their rod}

Most of the scam journals are online journals which require processing fees for publication without any peer-review or editing. Among reputational journals there are also those who charge the mandatory publication fees, such as Nature, Science, Cell Metabolism and others; while majority of journals publish manuscripts with NO CHARGE! The authors have to expect to go through the multiple steps of tough revision. First, the manuscripts go through a quick editorial screening according to the journals' scope and quality of the article. In case the study topic fits the scientific interests of the journal or provides unique and important information, the manuscript is sent to several reviewers. In the end, if the manuscript is accepted, then in most cases the only charge would be the cost of colored images in a printed version (online version of article is colored), and it is upon authors' desire. Thus, if the publication fee is very high or unreasonably low, it could either be a very high impact factor peer-reviewed journal, like Nature, Science, or likely a predatory one.

Firstly, researchers should find out whether the journal is indexed by Scopus, which however does not guarantee that the selected journal is not a scam. Check for the impact factor (IF) of the journal. Herein, it is important to understand that the impact factor is not an indicator of the journal quality to go by principle the higher the impact factor, the better the journal. The IF accounts for the citation frequency, which depends on the audience breadth of a particular field of research. For example, most environmental science-oriented journals are highly specialized and have lower impact factors than journals publishing cancer research. This is because fewer research groups work in the environmental science field and correspondingly fewer people cite the articles published in this field. However, if a journal has an impact factor, high or low, it would indicate that the journal is tracked by peer-reviewed literature databases such as Scopus and Clarivate Analytics, formerly known as Thomson Reuters, they practice routine review process and therefore could be considered for submitting the manuscript.

Other than affiliation with the scientific databases and having an impact index, there are other factors that need to be accounted while choosing the journal for submission. It is recommended to check the availability of information about editor'(s) scientific background, the affiliation and specialization of the editor(s) and board members, and regularity of publication. Also, if the journal contacts you back giving only a couple of weeks for the article to be published, it is more likely that this is a scam journal.
How to find a suitable journal for your article

To publish in Elsevier (Scopus) journals the authors can use the service 'Find the perfect journal for your article' on the website http://journalfinder.elsevier.com. To publish in Clarivate Analytics journals the match table on the 'EndNote' website https://www.myendnoteweb.com could be used. There are other websites such as http://jane.biosemantics.org/, https:// journalsuggester.springer.com/ and https://www.journalguide. $\mathrm{com} /$ that could be of help in finding an appropriate journal based on topics, abstracts and keywords. One should be realistic in choosing the target journal depending on the field of research. The first thing to do is to look over the available journals and learn the scope of the articles the journal publishes. This information is usually available on the main page of the journal website along with the impact factor, the editorial board information, and instructions for authors. It is helpful to look over the papers published in earlier issues to get an idea of the type of studies covered in the journal.

\section{Advantages and disadvantages of using intermediary services to prepare and submit a manuscript}

It is a common practice to use various services for translation and English correction. There are different intermediaries which offer assistance with the publication process. Their services include 1) Translation into English; 2) Selection of a suitable journal; 3) Correspondence with the editor(s), and 4) Promoting acceptance of the article for publication. The latter, however, raises doubts on the honesty of the organization, since acceptance of the article depends on the editor and the board decision only. These services are quite costly of around $\$ 1,800$ (USD), including mediation $(\sim \$ 1,000)$, translation $(\sim \$ 300-500)$ and a printing fee $(\sim 500)$. Availability of such services could be as helpful as deleterious because the journal chosen on behalf of authors by the third party could have low IF or be a scam journal because it is easier to get papers accepted by these journals. There are also many implicit fraudsters among intermediaries (SCI ${ }^{\circledR}$ Journal Citation Reports ${ }^{\circledR}$ ). We would recommend using the help for translation and grammatical editing but the authors are advised to choose the proper journal and communicate with the editor/publisher on their own. In most cases, the authors do not communicate with editors directly, the online submission is straightforward. You create an account, login and follow stepby-step instructions which are clear and simple. If considered by first-round editorial selection, you will receive an email from the editor regarding the manuscript revision, and if successful, regarding the acceptance for publication and final text and image corrections.

\section{Ethical issues related to journals' policy}

All journals strictly prohibit authors to submit their manuscript to more than one journal concurrently. The reasons for this are that the journals do not want to compete for the first right to publish the given work, the articles have not to be duplicated in several journals, and yet, multiple submissions would be a waste of time of designated reviewers, who are not payed and dedicate their valuable time to the review service. These reasons are strong enough to be followed regardless of authors desire to accelerate the process and expand the chance of the manuscript acceptance. 


\section{References}

1. Beall J. What I learned from predatory publishers. Biochemia medica: Biochemia medica. 2017;27(2):273-278.

2. Klemenkova K. Kazakhstan scientists published their scientific research in fake journals [In Russian]. Sputnik Kazakhstan. 2018. Retrieved from: https://ru.sputniknews.kz/society/20180104/4196030/uchenye-kazahstana-publikuyut-svoi-nauchnyeissledovaniya-v-falshivyh-zhurnalah.html

3. Sorokowski P, Kulczycki E, Sorokowska A, Pisanski K. Predatory journals recruit fake editor. Nature. 2017;543(7646):481-483.

4. Bohannon J. Who's afraid of peer review? Science. 2013;342(6154):60-65.

5. Martins TG, Costa AL, Moncada FJ, Martins RV. Hijacked scientific journals: a warning to researchers. Einstein (Sao Paulo). 2016;14(1):113. 